\title{
THE CHALLENGES OF ENGLISH LANGUAGE TEACHING IN INDONESIA
}

\author{
Roi Boy Jon ${ }^{1}$, Rahimah Embong ${ }^{2}$, Bambang Purnama ${ }^{3}$, Ari Safar Wadi ${ }^{4}$ \\ University of Sultan Zainal Abidin, Terengganu, Malaysia \\ University of Sultan Zainal Abidin, Terengganu, Malaysia \\ University of Sultan Zainal Abidin, Terengganu, Malaysia \\ University of Sultan Zainal Abidin, Terengganu, Malaysia \\ royboyjhon39@gmail.com
}

Received: $5 / 11 / 2021$

Accepted: 11/11/2021

Publication: 01/11/2021

\begin{abstract}
The widespread use of English worldwide has brought about a significant impact for human beings to date. In the education sphere mainly, many studies have been conducted to discover the issues in English instruction. Moreover, English teachers in Indonesia were highly encouraged to figure out the best method to teach and cope with any problems encountered by the students to achieve the best learning outcomes. Besides, the government had also tried its best endeavors to accustom the curriculum to the needs in this globalization era. However, the results have not always been as expected since teachers and students possessed divergent points of view linked with the implementation of English language instruction. Therefore, this scientific literature review discussed some issues related to English which included; English in Indonesia, English Language Teaching for Education, Teachers' Strategies to English Language Teaching, Problems of English Language Teaching, and Students' Perceptions towards English Language Teaching. Furthermore, the main aim of this paper was to acknowledge to the readers that the teachers and students essentially require English due to its crucial role in the development of Education in Indonesia.
\end{abstract}

Keywords: English Language Teaching, Teachers' Strategies, Problems of English Language Teaching, and Students' Perceptions towards English Language Teaching.

\section{Introduction}

English as the first world language and international Lingua Franca inevitably and undoubtedly plays essential roles for being spoken in some spheres of the work world to date (Rao, 2019). It is evidenced by the endeavors of governments worldwide to optimize English language proficiency as part of the escalating economy, education, and politics (Brooker, 2018).

In Indonesia, despite being heavily criticized at the beginning of its presence which was deemed to posses a threat to learners' multilingual backgrounds in terms of the cultural, moral, and behavioral aspects (Lauder, 2008), English is seen as a pointful means of communication since besides being implemented as instruction at higher educational institutions, it is also seen as a way to escalate one's social status. Thus, English language teaching has been an intrinsic part of the Indonesian educational system (Mappiasse et al., 2014). Furthermore, Lauder (2008) figured out that one of the reasons 
Indonesians learn English is its role on the international scale, which in turn leads them to compete globally.

Moreover, the status of English as a foreign language in Indonesia does not primarily underestimate its significance among societies. Since Indonesia belongs to one of the expanding circles (Kirkpatrick, 2020), which are commonly beyond the colonization of the inner-circle countries, some inner-circle countries (native speaking countries) are The United States, Britain, New Zealand, Australia, or Canada. On the other hand, countries that used to be colonized by the inner circles, in this case, Malaysia, Singapore, etc. are adopting English as their second or supplementary language and commonly spoken in their daily communication (Lee \& Jun 2016)

Furthermore, as Indonesia's most prioritized foreign language, English is deemed the modern means to communicate. In contrast, the Indonesian language plays a crucial role in linking the nation and vernacular languages as the traditional or historical status (Lie, 2017). Despite being not implemented in everyday communication, English is employed in a few places in Indonesia i.g. foreign enterprises, educational institutions, and foreign offices. Thus, it is encouraging that today's culture is beginning to recognize the importance of studying English, not merely for its function in knowledge, science, and technology, but also in economic activities and professional advancement (Gunantar, 2016).

Similarly, most people, particularly fresh graduates, see English as a gateway to widen job opportunities. Most employers seek competent people proven by the satisfying academic result and good English speaking proficiency (Sari \& Ed, 2014). Additionally, the globalization age was also perceived as imposing English as the prerequisite. They believe that Indonesians would be left behind and unable to compete on a global scale without English. Consequently, an increasing number of schools in Indonesia, ranging from kindergarten to university level, are trying to speak English as the language of teaching (Jayanti \& Norahmi, 2015).

\section{Method}

This article aims at explaining the English language teaching implemented in Indonesia. Moreover, the method employed is a qualitative library-research design which required the writer to collect the object materials from the previous studies on related English language teaching. Jones (1993) advocated that this type of research design will assist the researcher in attaching and identifying the factual sources or personal ideas to answer related research questions. The sources in this research include; the English curriculum, English teaching methods/strategies, students' perception towards English, and teachers' challenges in teaching English in Indonesia. Furthermore, the main focus of the writer in this paper is on the implementation of English and how teachers and students get adapted to the curriculum change on English from 2004 to 2013.

\section{Results and Discussions}

\section{The English Language Teaching for Education in Indonesia}

In Indonesia, the Ministry of National Education has long been concerned about the Teaching English as a Foreign Language (TEFL) problems. The primary approach employed so far is altering the curriculum, which is believed to be the solution (Suharjati, 2010). Thus, the teaching of English in the classroom learning process is heavily affected by what type of curriculum is implemented. Ekawati (2016) described a curriculum as the intended activities of students linked with the pedagogical subjects, ideas, sources, and practices aiming to scrutinize educational achievement objectives.

Moreover, from 2004 to 2013, the focus of English teaching was based on the Grammar Translation Method (GTM). Siregar (2018) spelled out GTM as a range of activities providing specific readings from L1 to the targetted language to produce meaning that associates a process and comprehension of both languages cognitively. The goals were to give understanding to the students, 
particularly the language learning, and to see the similar or different features between L1 (Indonesian) and L2 or foreign language (English) (Tugrul Mart, 2013). However, this type of approach was considered unsuccessful since knowing grammar and vocabulary will merely contribute to students' good exam results yet not the English mastery (Cai, 2012)

Today, the curriculum employed to improve Indonesia's education system is the 2013 curriculum (K-13), in effect from July 2013 to now. In this curriculum, teachers develop higher-order thinking skills by providing discussion-based activities, small group discussions, and classroom discussions to promote students' critical thinking skills (Indriyana \& Kuswandono, 2019). Moreover, the presence of the K-13 curriculum is to replace the previous KTSP program (Education Unit Level Curriculum), which was believed could merely assist students in gaining the knowledge but lack in skills and characters (Zaim, 2017). Furthermore, the curriculum change was generated by the awareness of Indonesian people about the development of the era, the world challenge, and the advancement of science and technology (Nasir, 2015).

Despite the critics in terms of the inadequacy of training, which has the potentials to the breakdown of the curriculum implementation in the classroom (Poedjiastutie et al., 2018), K-13 aspires to help Indonesians become more devout, industrious, innovative, and passionate citizens (Sofiana et al., 2019). Most importantly, this curriculum has been evolving the standardized process in the pedagogical sphere, which aims to achieve the ultimate standard of competence by preparing the teaching and learning to become more interactive, more challenging fun, and motivating (Habibi et al., 2017).

Moreover, some of the current curriculum's strengths are focusing on the meaning and communicative functions. Thus, developing students' English communication abilities is the ultimate purpose of learning English (Yufrizal, 2017). Furthermore, the Communicative Language Teaching (CLT) technique has been used in the 2013 ELT curriculum since it is expected to transition from a teacher-centered to a student-centered approach which leads to students learning the language's social functions, text structure, and grammar. This type of approach could enhance students' speaking confidence since it provides plenty of interactions and communication chances during the learning process (Ho, 2020). In addition, Gunawan (2017) found in his research that this curriculum could improve the learning process in terms of pre-teaching planning, implementing the learning undertakings, and learning activities evaluation.

Further, the principles of the 2013 curriculum seek to build a learning paradigm that moves from students to know to be students to find out, from teacher-centered to learner-centered, from contentbased to competency-based learning, and from partial to complete learning which in turn can assist the students to be more actively and critically engaged in English language learning process (Reswari, 2018). Gusnetti \& Mukhaiyar (2019) further explained the aims of K-13, which are to stimulate the students in their learning process and enable the students to observe, ask, and communicate the lesson they have gained.

A study also found plenty of points regarding English instructors' attitudes and practices of the 2013 curriculum's concepts and features in the context of English Language Teaching. One of the things admitted by the teachers is that the 2013 curriculum indicates a greater emphasis on learning (Darmawan et al., 2020). Consequently, more English language teaching specialists prefer suggesting that EFL teacher education include more courses in the curriculum that represent academic knowledge to produce English teachers with the best teaching skills. Therefore, Anjaniputra (2013) spelled out that teachers should be able to accustom the teaching strategies by considering students' proficiency levels, qualities, and material references that are compatible with their understanding.

\section{Teachers' Strategies To English Language Teaching In Indonesia}

In Indonesia, the categories of teaching competency in pedagogy, personality, and professionality have been regulated and become the measurement of an ideal teacher as they are integrated with the 
teachers' performance (Jabu, 2015). Therefore, it encourages them to think about improving their competency by implementing various strategies to improve students' learning outcomes. Upa (2020) explained teaching strategies as multiple actions implemented by the teachers aiming to conduct the teaching and learning process effectively and efficiently, which leads to successful learning objectives.

Moreover, one of the most numerous strategies required by the teachers to implement is how to attract students' interest, for it can stimulate students' English language learning (Yusimah \& $\mathrm{Hj}$, 2014). Yilmaz (2011) suggested that teachers are required to have self-efficacy, which affects their ability when establishing the teaching strategies and managing the classroom. Additionally, English teachers are needed to improve themselves by being present at a higher educational level or getting involved in teachers' service training to escalate their teaching competence (Gultom, 2015).

In addition, the understanding of both teachers and students is primarily becoming the prerequisite for the success of the learning process. Teachers should connect with the pupils and help them become more motivated (Gultom, 2015). No matter what approach is implemented, wellprepared teachers are supposed to know the media of instruction to foster students' involvement and use the tools in making plans and teaching (Skarpaas \& Hellekjær, 2021). Besides, the comfortability and enjoyability of the classroom climate are necessarily required by the teachers to achieve the learning goals (Mumary, 2017).

Furthermore, Adamson et al. (2013) figured out some strategies for students' development, which include the adaptation of language instruction for any rate of English competence, the use of English in various contexts (writing, repeating, highlighting), and the allowance for English students to converse in their language. Using the compatible teaching media is essentially required by the teachers to escalate students' motivation (Aini, 2013). Moreover, the teachers in Indonesia need the availability of English literature since it plays a crucial role in English teaching and learning, particularly to enrich students' knowledge in the four skills; writing, reading, speaking and listening (Novianti, 2016).

\section{Problems of English Language Teaching in Indonesia}

The incongruent expectation between teachers and learners during the learning process has affected the results and attitudes of teaching and learning (Xuan van ha, 2021). Teachers and learners are the significant determiners of academic outcomes. All learning activities are, therefore, successfully addressed if teachers and students involve together. Indeed, the teachers are the most crucial element in running the teaching and learning processes (Kaur, 2019). However, it is getting more difficult to get successful outcomes when the teachers do not have adequate communication proficiency, which influences the students' high expectation of good learning opportunities (König et al., 2016). Particularly, in English Language Teaching (ELT), if English teachers do not comprehend communicative language teaching philosophies, the accurate sociolinguistic context, and the students' need for language acquisition, it can be a problem in implementing teaching practices (Yulia, 2013).

In Indonesia, teachers and students deal with various problems and challenges in language teaching and learning. The issues partly come from students and English teachers (Mumary, 2017). Despite having learned English for years, plenty of students still find it challenging to communicate with the target language, particularly in speaking, which commonly requires them to transfer their ideas orally and the other skills (Abrar et al., 2018). As a result, several students are rarely motivated to study English due to the difficulties, poor learning resources, and limited time and opportunities to practice. Moreover, the students' motivation is the essential part that needs to be developed by the English teachers to involve them in English teaching and learning. Thus, it is one of the challenges for teachers to lead the instruction and interest the students to engage in the teaching.

Furthermore, the teachers also face many other challenges to optimize language learning, like students' different backgrounds and characteristics that affect their language acquisition. Consequently, most students have low proficiency in English language comprehension (S. S. N. A. Agung, 2019). It occurs since the students have poor vocabulary mastery. 
Therefore, it becomes an obstacle for teachers to teach the students with appropriate strategies to face this problem.

Besides, the problem is also related to the utilization of instructional media such as PowerPoint Presentations. The teachers cannot maximize their use to conduct the teaching and learning process effectively and attractively (Sukmahidayanti, 2015). This happens as the teachers' qualification that comes to teach English without any teaching training. Moreover, teaching English seems to be more challenging when it relates to teachers' problems due to a lack of experience (Karademir \& Gorgoz, 2019). Those who did not pass any teaching training enough might struggle to utilize the teaching method effectively.

Furthermore, the majority of English teachers are unprepared for the lessons they must provide. As they do not have an English bachelor's degree relevant for teaching primary pupils, their pedagogical understanding may be insufficient for teaching English (Hawanti, 2014). Additionally, inadequate time is another problem in teaching English. The lesson time is frequently limited; once or twice a week, one or two hours every day for various subjects to teach (Hamdan, 2011). As a result, the lesson plan does not go as planned, and the following session would frequently be a review of the previous unfinished teaching-learning materials. To make matters worse, they will be unable to detect the issues present in the learners' learning process.

Over-crowded English classes are also still one of the biggest problems faced by English teachers, and the effect of such a situation can be seen during the process of teaching and learning (Mumary Songbatumis, 2017). According to Badriah (2019), the over-crowded class is widely known as one difficulty teaching English. Consequently, the teacher will find new problems, which include more difficult class management, noisy class, and the teacher cannot pay attention to each student.

Several teachers are also rarely motivated to teach English due to the curriculum policy's complex demands that limit teachers' activities to serve innovative ideas for good quality of language teaching and learning (Darmawan et al., 2020). By the short time of teaching, limited facilities, and low salary, some teachers find it challenging to lead the instruction to achieve various indicators proposed in the curriculum 2013. Meanwhile, the teachers are lack knowledge of English Language Teaching (ELT) implementation, as stated in curriculum 2013 to refer to the performance of the scientific approaches and models, including project-based learning, problem-based learning, and discovery learning (Darmawan et al. 2020).

\section{Students' Perceptions towards English Language Teaching in Indonesia}

Teaching is complex work as it needs skills, thinking, decisions, and actions (Lamatokan, 2018). Teaching English is not only conveying materials to the students but also requires acting. Therefore, the English teachers are not merely serving students the English subject matter but also think, decide, and take appropriate action to educate them to be proficient in both oral and written English. Badriah (2019) points out that many ELT teachers have tried to create English classrooms, but they failed to get the meaning across, leading to students' incomprehension and resentment.

In Indonesia, English teachers carry out the instruction with numerous teaching styles, commonly referring to the students' necessities for language learning. Thus, students' perceptions are essential for estimating when to employ any teaching strategies in language learning. Moreover, teaching strategies that focus on teachers' central position, knowledge transmission, classroom teaching, and the teaching materials would highly critically affect how students perceive the teaching and learning process (Xia, 2020). Wulandari (2019) found that most students positively perceived the Indonesian language as the supporting language of instruction in the EFL classroom. Pardede (2018) advocated that more than three-quarters of students at secondary school in the capital of Indonesia (79\%) "agreed" and "strongly agreed" to use both English and Indonesian, while almost half (46\%) hated the notion of using full English.

Furthermore, some students have positive responses toward the teaching styles of their English teachers (Lamatokan, 2018), while few students disagree. It can be seen in the students' attitude toward 
English language teaching. The students show a positive attitude to the teacher's teaching style, in which they are satisfied with the language teaching and learning. According to the students' perspectives, they are happy with the teaching styles provided by the English teachers, in terms of the teacher's attitude in teaching, sufficient materials, teachers' learning strategies, and interesting media. It indicates that the English teachers successfully carry out language learning among students (Lamatokan, 2018). Furthermore, students' perception of English language teaching is also affected by the use of instructional media. Medium of instruction has been considered a tool of English language teaching for supporting students in teaching and learning (Alamsyah \& Darmawan, 2019). It is also one of the ways to assist students in improving their English language skills (Al Arif, 2019).

Similarly, other students from secondary levels have good views on the teachers' teaching styles. The students argue that the English teachers bring good attitude and interaction styles into English language teaching which in turn increases their learning motivation (Dewi et al., 2020). The English teachers are deemed as skilled and knowledgeable in conveying the materials when they attempt to communicate by using familiar vocabularies with the students and serve clear explanations with personal experience examples that support the subjects can be understandable. As the teachers' attitude and teaching styles, the students are satisfied with the learning activities.

However, several students show opposing responses to the English teaching and learning styles (Farjiiah et al., 2019) as they are not satisfied with the learning activities. On the one hand, they assume that the English teachers rarely use English in their teachings. The materials are not accordant with the student's daily activities, and the media were barely implemented. On the other hand, they opine that the class was boring, the lessons are not clearly explained, materials to discuss are not well designed, short time to practice and the feedback of daily homework are rarely provided by the English teachers.

Additionally, since the internet is a crucial learning resource for students, language learning is mediated inside and outside the classroom or is well-known as the flipped classroom. A flipped classroom is a new model of teaching in Indonesia that transfers the teaching materials outside the school (home) by utilizing media like video and podcast, involved with the content, and through problem-solving or group work, which is then discussed in the class (Blair et al., 2016). The students' response toward the use of Flipped classroom model in Indonesia performs numerous judgments. Generally, they perceive that the Flipped classroom implementation is good particularly in escalating the academic outcomes as the result of students' high motivation and positive attitudes towards this strategy (Akçayır \& Akçayır, 2018). Nonetheless, the students prefer to learn in the classroom rather than view lecture videos or read subjects at home to prepare their materials before class as what in Flipped classroom model (Afrilyasanti et al., 2017). The students are unmotivated to view the lecture videos due to the repeated content that the class teachers repeatedly conduct. As a result, several students are not well prepared to participate in the classroom activities. Hence, they are more actively engaged in classroom activities than watching videos (online self-learning).

Most importantly, as the impact of Covid-19, teachers and students recently are forced to replace physical learning with an online system. Therefore, online instruction is a big deal of the national education ministry of Indonesia to operate the teaching and learning process amid the pandemic period demanding all educational fields from primary schools to higher institutions (Hadriana et al., 2021). Overall instructional activities are required to employ online to cut the spread of Covid-19 effects. Consequently, teachers and students carry out learning activities, including English language teaching, through varied e-learning platforms such as Zoom Meetings, Rumah Belajar, WhatsApp, Quipper School, and Ruang Guru. Regarding this issue, the students involved in online activities advocate that the online instruction is enjoyable as it is accessible, helpful, and engaging (A. S. N. Agung \& Surtikanti, 2020). The study conducted by Rakhmanina (2021), exploring students' perceptions toward Online English learning, indicates that most students were actively immersed in online instruction rather than those who do not. She (2021) explains that the rest of the students cannot participate due to 
poor access or limited connectivity. WhatsApp is an affordable and enjoyable learning medium for students as it is straightforward to access (Susila et al., 2020).

\section{Conclusion}

In Indonesia, English is seen as crucial as it is required in many sectors to fulfill several needs of society, including education, culture, economy, and politics. The presence of English has significantly contributed a profound effect toward Indonesia's necessity in the enriching economy, society, and education. Moreover, teaching English in Indonesia is addressed entirely by referring to the curriculum regulations made by the national education ministry. Indonesia's curriculum policy has changed regularly from 2004 to 2013 as it has been named as KTSP to K-13. KTSP was a temporary curriculum in 2004 that demanded English Language Teaching, conducted using Grammar Translation Method (GTM). However, it was considered as unsuccessful as it only helped students in English examination results and not the English attainment.

In 2013, curriculum K-13 was built to replace the KTSP curriculum as the change of era, world challenge, and science and technology enhancement. 2013 curriculum is considered good as it adopts communicative language teaching (ELT) approach and emphasizes on from teacher-centered to learner-centered, from content-based to competency-based learning, and from partial to complete learning exposes students' activeness and critics while being engaged in English language learning process. Indonesian English teachers employ various learning strategies to bring effective and efficient instruction for excellent English language outcomes. The most crucial role of teachers is encouraging their students to engage in the learning process actively. Indeed, teachers should be able to escalate students' interest in learning by serving specific teaching methods. In Indonesia, teachers are emphasized to involve in a teachers' training program to enhance their teaching competencies. However, teachers and students in Indonesia deal with problems and challenges in language teaching and learning. English Foreign Language (EFL) students in Indonesia find it challenging to learn English as a foreign language different from their mother language (Indonesia). As a result, they are rarely engaged in language learning due to its difficulty, poor learning resources, and limited time and opportunity to practice.

On the other hand, several teachers are not proficient in applying instructional media to increase students' learning motivation. It happens due to some teachers who do not participate in any teaching training. Particularly, in the pandemic covid-19, teachers attempt to maximize the learning dealing with complex demands of the curriculum, including poor learning strategies, limited time of teaching, and lack of learning access. Perceptions of students toward language learning in Indonesia indicate various judgments depending on how teachers bring their teaching styles into the learning activities. Some students agree with the teaching styles addressed by the teachers as they can carry out satisfying learning with a good attitude in teaching, the presence of sufficient materials, the use of appropriate learning strategies, and the implementation of interesting media. On the contrary, some students disagree with the teaching styles conducted by the teachers as they rarely use English in their teachings, irrelevant materials with the students' daily activities, and the media were barely implemented. Besides, the students do not expose the boring class, unclear lessons, unprepared materials, short time of practice, and rare feedback giving. Indeed, amid the pandemic era, students perceive it interesting to address online learning as they think it is easy, helpful, enjoyable, and engaging.

\section{References}

Abrar, M., Jambi, U., Mukminin, A., Jambi, U., Habibi, A., Jambi, U., \& Marzulina, L. (2018). “If our English isn't a language, what is it?" Indonesian EFL Student Teachers ' Challenges Speaking English. January. https://doi.org/10.46743/2160-3715/2018.3013

Adamson, K., Santau, A., \& Lee, O. (2013). The Impact of Professional Development on Elementary Teachers' Strategies for Teaching Science with Diverse Student Groups in Urban Elementary 
Schools. J Sci Teacher Educ, 553-571. https://doi.org/10.1007/s10972-012-9306-z

Afrilyasanti, R., Cahyono, B. Y., \& Astuti, U. P. (2017). Indonesian EFL Students' Perceptions on the Implementation of Flipped Classroom Model. Journal of Language Teaching and Research, 8(3), 476-484. https://doi.org/10.17507/jltr.0803.05

Agung, A. S. N., \& Surtikanti, M. W. (2020). Students' Perception of Online Learning during COVID-19 Pandemic: A Case Study on the English Students of STKIP Pamane Talino. SOSHUM : Jurnal Sosial Dan Humaniora, 10(2), 225-235. https://doi.org/10.31940/soshum.v10i2.1316

Agung, S. S. N. A. (2019). Current Challenges in Teaching English in the Least-developed Region in Indonesia. Journal of Social Sciences and Humanities, 9(3), 266-271.

Aini, W. N. (2013). Instructional Media In Teaching English To Young Learners. 1(1), 196-205.

Akçayır, G., \& Akçayır, M. (2018). The flipped classroom: A review of its advantages and challenges. Computer and Education, 335-345. https://doi.org/https://doi.org/10.1016/j.compedu.2018.07.021

Al Arif, T. Z. Z. (2019). Indonesian University Students' Perception and Expectation towards ICT Use in Learning English as a Foreign Language. IJELTAL (Indonesian Journal of English Language Teaching and Applied Linguistics), 4(1), 133. https://doi.org/10.21093/ijeltal.v4i1.348

Alamsyah, A., \& Darmawan, R. (2019). Students 'Perceptions Toward Language Teaching Media. 113.

Anjaniputra, A. G. (2013). Teacher's Strategies in Teaching Speaking To Students At Secondary Level. Journal of English and Education, 1(2), 1-8.

Badriah, S. (2019). Teachers' Challenges in Classroom Management in Teaching English At Mas Mahdaliyah Jambi. 1-70.

Blair, E., Maharaj, C., \& Primus, S. (2016). Performance and perception in the flipped classroom. Education and Information Technologies, 21(6), 1465-1482. https://doi.org/10.1007/s10639015-9393-5

Brooker, D. (2018). English For Development.

Cai, H. (2012). E-learning and English Teaching. Elsevier, 2, 841-846. https://doi.org/10.1016/j.ieri.2012.06.180

Darmawan, R., Wahyudin, D., \& Ali, M. (2020). English Language Teaching Curriculum in Indonesia: Senior High School Teachers' Perspectives and Practices. Proceedings Ofthe Borneo International Conference on Education and Social Sciences, 229, 248-254. https://doi.org/10.5220/0009019402480254

Dewi, N. K. P. N., Dewi, N. L. P. E. S., \& Suptrianti, G. A. P. (2020). The Students' Perceptions on English Teachers' Teaching Style and How It Affects on Learning Motivation. Jurnal Ilmiah Pendidikan Dan Pembelajaran, 4(3), 546-554.

Ekawati, Y. N. (2016). The Implementation Of Curriculum 2013 : A Case Study Of English Teachers ' Experience. ELLD Journal, 7(1), 84-90.

Farjriah, N., Gani, A. S., \& Samad, A. I. (2019). Students' Perception toward Teacher's Teaching Strategies, Personal Competence, and School Facilities. English Education Journal (EEJ), 10(1), $16-34$.

Gultom, E. (2015). English Language Teaching Problems in Indonesia. Proceeding: 7th International Seminar on Regional Education, 3, 1234-1241.

Gunantar, D. A. (2016). The Impact Of English As An International Language On English Language Teaching In Indonesia. Journal Lof Language and Literature, 1(April), 141-151.

Gunawan, I. (2017). Indonesian Curriculum 2013: Instructional Management, Obstacles Faced by Teachers in Implementation and the Way Forward. 128(Icet), 56-63.

Gusnetti,Mukhaiyar,S.R.(2019).To_Make_The_Curriculum_Change_Of_2013_From_Curriculum_Kt sp_Case_Study_Learning_Of_Indonesian_Language_In_Sma_

Https://Www.Researchgate.Net/Publication/336553248 
Habibi, A., Mukminin, A., Sofwan, M., \& Sulistiyo, U. (2017). Implementation of Classroom Management by English Teachers at High Schools in Jambi, Indonesia. Studies in English Language and Education, 4(2), 172-189.

Hadriana, Mahdum, Isjoni, Furtra, D., \& Primahardani, I. (2021). Online Learning Management in the Era of Covid-19 Pandemic at Junior High Schools in Indonesia. Journal of Information Technology Education: Research, 20, 351-383.

Hamdan, K. M. and A. R. (2011). The Teaching Constraints of English as a Foreign Language in Indonesia: The Context of School-Based Curriculum. SOSIOHUMANIKA, 4(2), 287-300.

Hawanti, S. (2014). Implementing Indonesia's English language teaching policy in primary schools: The role of teachers; knowledge and beliefs. International Journal of Pedagogies and Learning, 9(2), 162-170. https://doi.org/10.1080/18334105.2014.11082029

Ho, Y. C. (2020). Sport \& Tourism Education Communicative language teaching and English as a foreign language undergraduates ' communicative competence in Tourism English. Journal of Hospitality, Leisure, Sport \& Tourism Education, 27(1), 100271. https://doi.org/10.1016/j.jhlste.2020.100271

Indriyana, B. S., \& Kuswandono, P. (2019). Developing Students ' Higher Order Thinking Skills ( HOTS ) in Reading: English Teachers' Strategies in Selected Junior High Schools. Journal of English Teaching, 5(October 2019), 204-216.

Jabu, B. \& S. (2015). The Problems in Professional Competence of Teachers in Teaching English Subject at Vocational High Schools. ELT Worldwide, 2(2), 1-15.

Jayanti, F. G., \& Norahmi, M. (2015). EFL: Revisiting ELT Practices in Indonesia. Journal on English as a Foreign Language, 4(1), 5. https://doi.org/10.23971/jefl.v4i1.70

Jones, R. L. (1993). Library research. In Journal of AHIMA / American Health Information Management Association (Vol. 64, Issue 2). Princeton University Press. https://doi.org/10.1007/978-1-349-19936-5_3

Karademir, C. A., \& Gorgoz, S. (2019). English Teachers' Problems Encountered in Teaching Four Basic Language Skills. International Education Studies, 12(4), 118. https://doi.org/10.5539/ies.v12n4p118

Kaur, S. (2019). Role of a Teacher in Student Learning Process. International Journal of Business and Management Invention (IJBMI), 8(12), 41-45.

Kirkpatrick, A. (2020). Englishes in the expanding circle: Focus on Asia. Russian Journal of Linguistics, 24(3), 551-568. https://doi.org/10.22363/2687-0088-2020-24-3-551-568

König, J., Lammerding, S., Nold, G., Rohde, A., Strauß, S., \& Tachtsoglou, S. (2016). Teachers ' Professional Knowledge for Teaching English as a Foreign Language: Assessing the Outcomes of Teacher Education. Journal of Teacher Education. https://doi.org/10.1177/0022487116644956

Lamatokan, Al. (2018). Students' Perception toward Teachers' Teaching Styles and the Use of Learning Strategies in Teaching English. Eralingua: Jurnal Pendidikan Bahasa Asing Dan Sastra, 2(2), 41-46.

Lauder, A. (2008). the Status and Function of English in Indonesia: a Review of Key Factors. Makara Human Behavior Studies in Asia, 12(1), 9. https://doi.org/10.7454/mssh.v12i1.128

Lee, Y. H., \& Jun, K. S. (2016). The inner-circle vs. The outer circle or British English vs. American English. Proceedings of the 30th Pacific Asia Conference on Language, Information and Computation, PACLIC 2016, I, 339-346.

Lie, A. (2017). English And Identity In Multicultural Contexts : Issues, Challenges, and Opportunities. TEFLIN Journal, 28(1), 2-22.

Mappiasse, S. S., Johari, A., \& Sihes, B. (2014). Evaluation of English as a Foreign Language and Its Curriculum in Indonesia: A Review. Journal of English Language Teaching, 7(10), 113-122. https://doi.org/10.5539/elt.v7n10p113 
Mumary, A. (2017). Foreign Language Challenges in Teaching English Faced by English Teachers at MTsN Taliwang, Indonesia. Journal of Foreign Language Teaching and Learning, 2(2), 2-14.

Mumary Songbatumis, A. (2017). Challenges in Teaching English Faced by English Teachers at MTsN Taliwang, Indonesia. Journal of Foreign Language Teaching and Learning, 2(2). https://doi.org/10.18196/ftl.2223.

Nasir, Z. I. (2015). Teaching English Based on 2013 Curriculum at Junior High School in Gowa. 1(2), 246-256.

Novianti, N. (2016). English Literature Teaching: An Indonesian Context. Indonesian Journal of Linguistics, 6(1), 42-49.

Pardede, P. (2018). Use of Mother Tongue in EFL Classes of Secondary Schools In Jabodebek: Students' and Teachers' Perception. JET (Journal of English Teaching), 4(2), 62. https://doi.org/10.33541/jet.v4i2.831

Poedjiastutie, D., Akhyar, F., Hidayati, D., \& Gasmi, F. N. (2018). Does Curriculum Help Students to Develop Their English Competence? Arab World English Journal, 9(2), 175-185.

Rakhmanina, L., Martina, F., Halolo, F. B., Syafryadin, S., \& Noermanzah, N. (2021). Students' Perception on Online English Learning during Covid-19 Pandemic Era. Silampari Bisa: Jurnal Penelitian Pendidikan Bahasa Indonesia, Daerah, Dan Asing, 3(2), 428-439. https://doi.org/10.31540/silamparibisa.v3i2.1150

Rao, P. S. (2019). The role of English as a global language. Research Journal of English (RJOE), 4(January), 65-79. https://www.rjoe.org.in/vol4iss1.html

Reswari, G. P. A. (2018). Teaching English in the KTSP Curriculum and 2013 Curriculum (Issue 21). Queen's University, Belfast.

Sari, R., \& Ed, B. M. (2014). Exploring Indonesian Graduates' English Language Skills and Companies 'English Language Skills Requirements in East. 19(6), 44-56.

Siregar, R. (2018). Grammar Based Translation Method in Translation Teaching. International Journal of English Language and Translation Studies, 6(2), 148-154.

Skarpaas, K. G., \& Hellekjær, G. O. (2021). International Journal of Educational Research Open Vocational orientation - A supportive approach to teaching L2 English in upper secondary school vocational programs. International Journal of Educational Research Open, 2-2(May), 100064. https://doi.org/10.1016/j.ijedro.2021.100064

Sofiana, N., Mubarok, H., \& Yuliasri, I. (2019). English Language teaching in secondary schools: An analysis of the implementation of Indonesian ELT 2013 curriculum. International Journal of Instruction, 12(1), 1533-1544. https://doi.org/10.29333/iji.2019.12198a

Suharjati, F. (2010). History of Teaching English. 2(03), 161-168.

Sukmahidayanti, T. (2015). The Utilization of Instructional Media in Teaching English to Young Learners ( A Case Study of an Elementary School Teacher in Bandung ). Journal of English and Education, 3(2), 90-100.

Susila, H. R., Qosim, A., \& Rositasari, T. (2020). Students' Perception of Online Learning in Covid19 Pandemic: A Preparation for Developing a Strategy for Learning From Home. Universal Journal of Educational Research, 8(11B), 6042-6047. https://doi.org/10.13189/ujer.2020.082240

Tugrul Mart, C. (2013). The Grammar-Translation Method and the Use of Translation to Facilitate Learning in ESL Classes. Journal of Advances in English Language Teaching, 1(4), 103-105. www.european-science.com/jaelt

Upa, Y. (2020). English Teacher Identity Construction: Indonesian Teachers ' Motivation and Strategies in Teaching English for Special. Professional Journal of English Education, 3(2), 311-321.

Wulandari, D. (2019). Students' Perceptions Toward Teacher's Indonesia Language Use in EFL Classroom. Sustainability (Switzerland), 11(1), 1-14.

Xia, J. (2020). Teaching for Student Learning: Exploration of Teaching Strategies Based on Protocol- 
IJEAL (International Journal of English and Applied Linguistics)

Volume : 1 | Number 3 | December 2021 | E-ISSN : 2787-9482 |DOI: doi.org/ijeal.v1n1.1157

Guided Learning. Science Insights Education Frontiers, 5(1), 451-467. https://doi.org/10.15354/sief.20.ar011

Yilmaz, C. (2011). Teachers ' Perceptions of Self-Efficacy, English Proficiency, and Instructional Strategies. Social Behavior and Personality, 39(1), 91-100. https://doi.org/10.2224/sbp.2011.39.1.91

Yufrizal, H. (2017). Teachers and students ' perceptions of communicative competence in English as a foreign language in Indonesia. Academic Journals, 12(17), 867-883. https://doi.org/10.5897/ERR2017.3243

Yulia, Y. (2013). Teaching Challenges in Indonesia: Motivating Students and Teachers' Classroom Language. Indonesian Journal of Applied Linguistics, 3(1), 1-16.

Yusimah, D., \& Hj, P. (2014). A study of teachers ' strategies to develop students' interest in learning English as a second language. Procedia - Social and Behavioral Sciences, 134, 188-192. https://doi.org/10.1016/j.sbspro.2014.04.238

Zaim, M. (2017). Implementing Scientific Approach to Teach English at Senior High School in Indonesia. Asian Social Science, 13(2), 33-40. https://doi.org/10.5539/ass.v13n2p33 